\title{
Bidirectional ventricular tachycardia due to hypokalaemia
}

\author{
Inês Santos, João Alves Teixeira, Catarina Costa, Luis Vale
}

Medicina 2.1, Hospital de Santo António dos Capuchos, Centro Hospitalar Lisboa Central, Lisboa, Portugal

\section{Correspondence to} Dr Catarina Costa, costa.catarina@gmail.com

Accepted 25 November 2018

\section{DESCRIPTION}

Bidirectional ventricular tachycardia (BDVT) is a regular ventricular tachyarrhythmia (VT) with two different QRS morphologies alternating at a rate typically between 140 and $180 \mathrm{bpm} .{ }^{1}$ There are not many known related causes and the most common include digoxin toxicity, catecholaminergic polymorphic VT, myocarditis and myocardial infarction. $^{2} 3$

We report a case of a 81-year-old woman, with a known history of diabetes mellitus and hypertension, admitted at the emergency department for prostration, diarrhoea and vomiting. Biochemistry tests on admission revealed severe ionic deficit, with a potassium level of $1.7 \mathrm{mmol} / \mathrm{L}$. No serum digoxin levels were measured because there was no history of therapy with this drug. The 12-lead ECG (figure 1) revealed a BDVT pattern with a heart rate of $153 \mathrm{bpm}$. Endovenous potassium replacement was initiated with an immediate ECG pattern normalisation (figure 2). The authors present a case of BDVT, a rare arrhythmia with a cause not previously described.

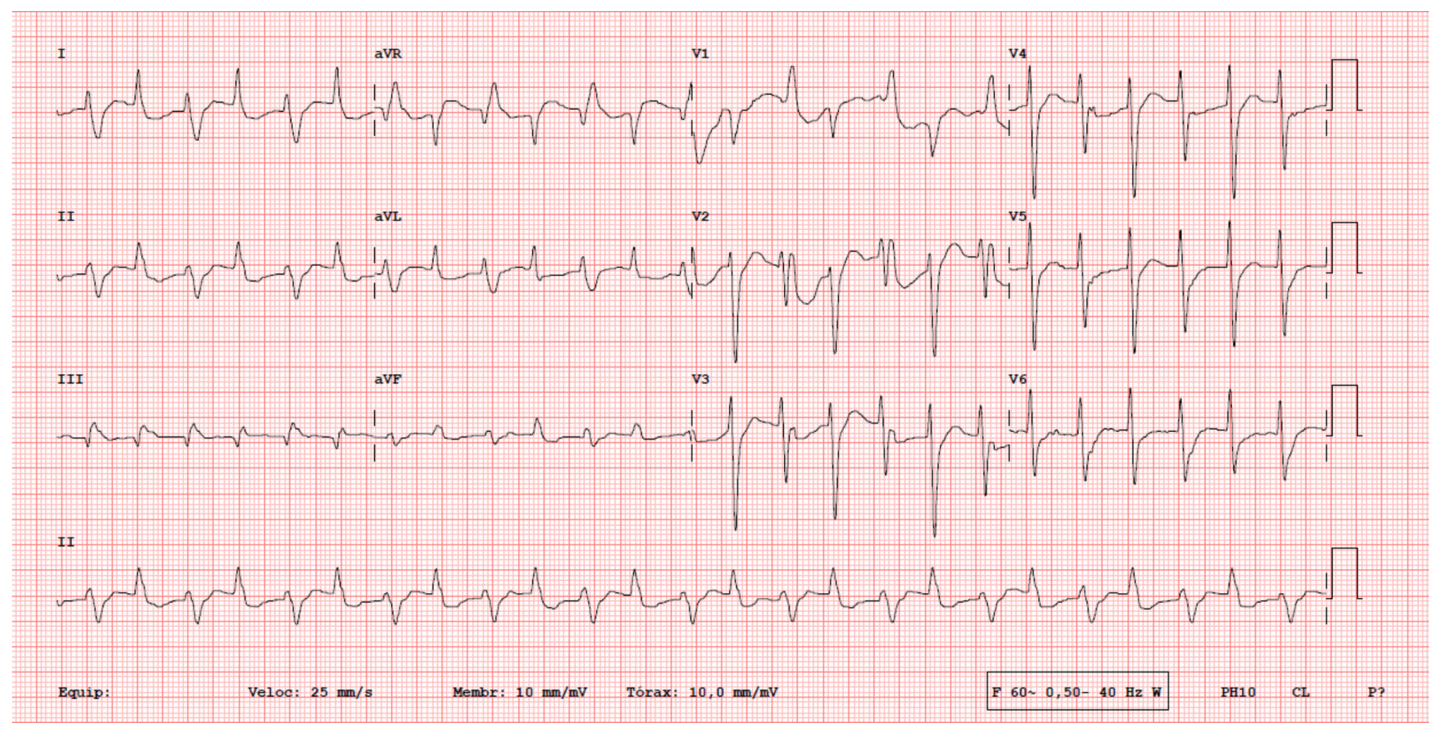

Figure 1 Bidirectional ventricular tachycardia.

Check for updates

(C) BMJ Publishing Group Limited 2018. No commercial re-use. See rights and permissions. Published by BMJ.

\footnotetext{
To cite: Santos I,

Alves Teixeira J, Costa C,

et al. BMJ Case Rep

2018;11:e228195.

doi:10.1136/bcr-2018-

228195
}

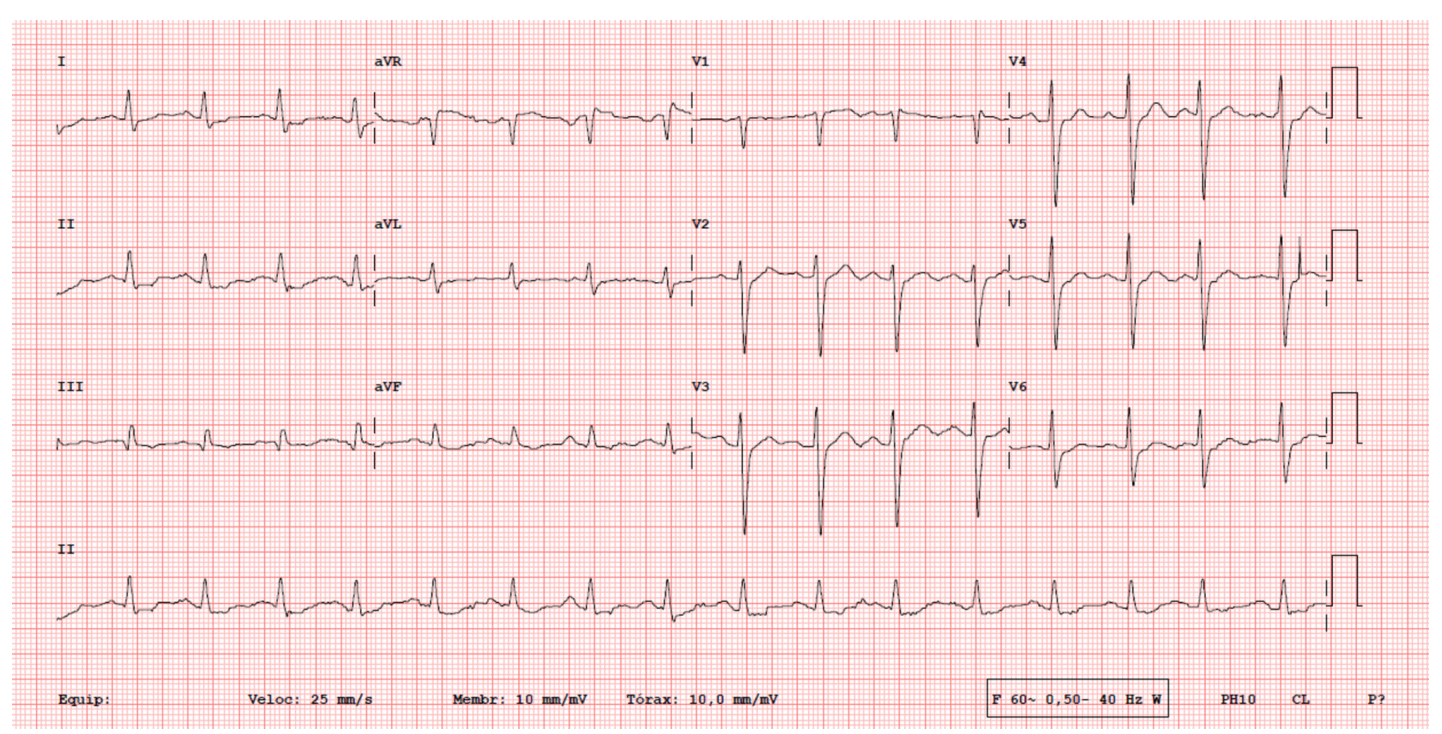

Figure 2 Sinus rhythm. 


\section{Learning points}

- Bidirectional ventricular tachycardia (BDVT) is a rare form of ventricular arrhythmia with a limited number of known causes described in the literature.

- As described in this case, hypokalaemia was assumed as the cause of BDVT.

- When confronted with this ECG pattern, hypokalaemia should be part of the differential diagnosis.

Contributors IS: planning, reporting, conception, interpretation of data. JAT: design, analysis. CC: conduct, acquisition of data. LV: analysis.
Funding The authors have not declared a specific grant for this research from any funding agency in the public, commercial or not-for-profit sectors.

Competing interests None declared.

Patient consent for publication Obtained.

Provenance and peer review Not commissioned; externally peer reviewed.

\section{REFERENCES}

1 Richter S, Brugada P. Bidirectional ventricular tachycardia. J Am Coll Cardiol 2009;54:1189.

2 Valent S, Kelly P. Images in clinical medicine. Digoxin-induced bidirectional ventricular tachycardia. N Engl J Med 1997;336:550.

3 Park YH, Kim J. Bidirectional ventricular tachycardia in a patient with acute myocardial infarction and aortic stenosis. Int J Cardiol 2013;162:e41-e42.

Copyright 2018 BMJ Publishing Group. All rights reserved. For permission to reuse any of this content visit

https://www.bmj.com/company/products-services/rights-and-licensing/permissions/

BMJ Case Report Fellows may re-use this article for personal use and teaching without any further permission.

Become a Fellow of BMJ Case Reports today and you can:

- Submit as many cases as you like

- Enjoy fast sympathetic peer review and rapid publication of accepted articles

- Access all the published articles

Re-use any of the published material for personal use and teaching without further permission

For information on Institutional Fellowships contact consortiasales@bmjgroup.com

Visit casereports.bmj.com for more articles like this and to become a Fellow 